\title{
LOCAL PARALYSIS IN CHILDREN AFTER INJECTIONS
}

\author{
BY \\ J. K. MARTIN, M.B., B.S., M.R.C.P., D.Obst.R.C.O.G., D.C.H. \\ From the Department of Child Health, Guy's and Evelina Hospitals, London
}

(Received for Publication, October 24, 1949)

This paper has been written to draw attention to the association between intramuscular injections and flaccid paralysis of one limb. Seventeen affected children have been examined and followed up personally. The records of a further 60 to 70 cases have been available and have been used to provide information not clearly brought out in the shorter series. Cases in which injection preceded paralysis by more than 28 days have been excluded. The aetiology of the paralysis and the relationship it bears to the injection are discussed.

\section{Clinical Features}

TABLE 1

Analysis of InCidence in Relation to Age (IN Years)

\begin{tabular}{c|c|c|c|c}
\hline $6 / 12-1$ & $1-1 \frac{1}{2}$ & $1 \frac{1}{2}-2$ & $2-3$ & Total \\
\hline 7 & $7^{*}$ & 1 & 2 & 17 \\
\hline
\end{tabular}

* Includes two cases following penicillin injections.

The average age of this group was one year, the youngest child being seven months, and all the children were under three years. In a further 39 cases occurring between 1941 and 1949 in which the age incidence was known, the average age was $4 \frac{1}{2}$ years and ranged from 9 months to 14 years. The higher age incidence was accounted for because children of school age represented the largest numbers of those inoculated in the early days of the immunization campaign. Taken as a whole the age groups reflect the average age at which immunization is carried out.

Taking all known cases, girls were slightly more frequently affected than boys.

Incubation Period. The average time between the injection and the onset of the paralysis was 16 days, the majority of cases occurring between 7 and 21 days, the shortest being 3 days and the longest 26 days.

Prodromal Symptoms. In this series there were without exception constitutional disturbances either preceding or at the time of onset of the paralysis. Nine patients had a history of fretfulness, lethargy, loss of appetite, or pyrexia within one to four days of becoming paralysed. In the remaining eight patients an ' upper respiratory infection,' pyrexia, or fretfulness occurred at some time following inoculation. Neck rigidity was found in four and pyrexia in five patients seen at the time of onset.

Pain and tenderness was not apparent either preceding or accompanying the paralysis. As all these children were under three years of age this does not of necessity entirely exclude its presence.

Paralysis. The onset was sudden, with a flaccid paralysis of the whole limb as a rule, but frequently sparing the fingers and toes.

The frequency with which an upper limb was affected, and in particular the left, would appear to reflect the commonest site for inoculation, namely the left deltoid muscle. The left arm was paralysed four times as frequently as the right, taking all known cases.

There was no affection of the cranial nerves and in only two cases (Cases 11 and 14) was any paralysis noted other than in the limb involved, and then it was only of a transient nature. Sensation, as gauged by pin prick, appeared to be normal.

The muscles involved in the arm were of constant distribution, namely, the supraspinatus, rhomboids, infraspinatus, teres minor, biceps, brachialis, deltoid, supinator longus, serratus magnus, pectoralis major, teres major, latissimus dorsi, triceps, and the extensors of the wrist and fingers. This distribution corresponds to the muscles supplied by the motor roots of the fifth, sixth, and seventh cervical segments of the spinal cord. The corresponding tendon reflexes were absent.

In the legs the muscles most constantly involved were the quadriceps and the anterior tibial group. Two cases at the onset showed complete flaccid paralysis of the leg except for some movement in the toes.

\section{Course and Prognosis}

The sequence of events in those cases involving an arm which recovered was for the wrist extensors to begin to act within a few days. The rhomboids, serratus magnus, teres major, and usually the teres 
minor and the pectorals, recovered early. The biceps group and then the triceps group began to function next, about two to three months after the onset. The deltoid and spinati were the last muscles to recover, often taking a year or more. Considerable wasting of the affected muscles occurred. Of the 12 cases recorded in detail, two (Cases 2 and 11) have not been followed up for a sufficient length of time to give a prognosis. Of the remainder, Case 12 has made an almost complete recovery, there being a little residual weakness in the deltoid only. Four others (Cases 1, 5, 6, 10) have made good partial recoveries, and of these at least two will probably be complete. The other five cases include one (Case 9), in which there has been virtually no improvement after 18 months, and four (Cases 3, $4,7,8$ ) in which the shoulder girdle and upper arm muscles have remained paralysed after a year. Some improvement in the muscles of the upper arm in these cases might be anticipated. A study of further records tended to confirm that about $50 \%$ made a good functional recovery.

As in anterior poliomyelitis the prognosis is difficult to assess in the early stages and recovery can start 9 to 12 months after the onset, continuing up to two years or possibly longer.

In the cases in which a leg was involved none made a complete recovery in periods of up to 18 months. Of the two cases (Cases 13 and 16) in which initially the whole of one lower limb was paralysed, one patient is left with no action of the quadriceps and tibialis anterior after nine months, and the other still has extensive paralysis after six months. Of the other three a good partial recovery has occurred in one, and in two slight improvement only.

\section{Investigations}

Lumbar Puncture. The cerebrospinal fluid was examined in seven cases. The other cases were not seen until too long after the onset to justify such a procedure. In the cases mentioned, details of which are given in Appendix $\mathbf{A}$, the changes included a raised cell count and serum protein level and were consistent with those found in poliomyelitis.

Schick Test. This had been done on only one patient, who proved to be Schick-positive and was given two further immunizing doses without untoward effects.

Examination of Stools for Poliomyelitis Virus. Animal incculation from Case 11 was tried, but the result was negative.

Electrical Reactions. Electrical testing of the affected muscles showed the reaction of degeneration. As in other lesions of the lower motor neurone type these reactions are probably of more value in prognosis than diagnosis.

\section{Treatment}

Treatment similar to that employed in poliomyelitis was used. Paralysed muscles were splinted, and cases involving an arm were put up in an 'aeroplane ' abduction splint. The most important part of physical treatment was to remove all splinting at least twice a day and put the joints through a full range of movement. As soon as any voluntary power returned graduated active movements were given. At this stage the child was encouraged to use the limb as much as possible during certain periods of the day. Galvanism was used in some cases in which the reaction of degeneration was obtained in order to maintain muscle bulk (Gutmann and Guttmann, 1944). Where possible, patients attended a physiotherapy department three or more times weekly.

\section{Details of Injections Used}

There appears to be no relationship between the substance inoculated and the paralysis. Materials used included A.P.T., pertussis vaccine alone or combined, and T.A.F. Other writers (Walshe, 1945; Parsonage and Turner, 1948) report the occurrence of paralysis after T.A.B., tetanus toxoid, and antityphus vaccine, but these cases were probably of a different aetiology. In this series there are two cases following penicillin given as treatment for boils and stomatitis respectively. The material injected was produced by at least six different manufacturers. In several cases a specimen from the same batch of material was obtained and returned to the manufacturers for detailed examination without any harmful agent being found. Cases occurred after the first, second, or third immunizing dose.

No local reactions occurred in this series.

Apart from the constitutional symptoms mentioned, only one patient (Case 11) became pyrexial immediately after inoculation, and in this patient the paralysis developed within three days. In the remainder no immediate generalized reactions and nothing akin to serum sickness developed.

\section{Epidemiology}

It is a little difficult to draw any conclusions from such a small series as shown in Table 2, particularly when it is realized that cases were chiefly sought in the years 1946-1949. Taking a larger series of 67 cases (Table 3 ) there is suggestive evidence that these cases occur chiefly when there is a high prevalence of poliomyelitis. 
TABLE 2

Annual Incidence of Present Series

\begin{tabular}{|c|c|c|c|}
\hline \multicolumn{3}{|l|}{ Year } & \multirow{2}{*}{$\begin{array}{l}\text { No. of Cases of Paralysis } \\
1 \\
2 \\
0 \\
5^{*} \\
8 \dagger \\
1 \text { (first six months) }\end{array}$} \\
\hline $\begin{array}{l}1944 \\
1945 \\
1946 \\
1947 \\
1948 \\
1949\end{array}$ & $\begin{array}{l}\ldots \\
\ldots \\
\ldots \\
\ldots \\
\ldots\end{array}$ & $\begin{array}{l}\cdots \\
\cdots \\
\cdots \\
\cdots \\
\cdots\end{array}$ & \\
\hline
\end{tabular}

TABLE 3

INCIDENCE OF PARALYSIS AFTER INJECTION COMPARED WITH POLIOMYELITIS AND POLIO-ENCEPHALITIS (NOTIFICATIONS) FOR ENGLAND AND WALES

\begin{tabular}{c|c|c}
\hline Year & Cases of Paralysis & Notifications \\
\hline 1941 & 10 & 959 \\
1942 & 6 & 674 \\
1943 & 5 & 456 \\
1944 & 6 & $532^{*}$ \\
1945 & 9 & $858^{*}$ \\
1946 & 0 & $673^{*}$ \\
1947 & 18 & $7,766^{*}$ \\
1948 & 12 & $1,840^{*}$ \\
1949 & 12 & \\
& (first nine months) & \\
\hline
\end{tabular}

TABLE 4

Seasonal InCidence of 17 Cases

\begin{tabular}{l|c|c|c|c|c|c|c}
\hline Month & No. & Month & No. & Month & No. & Month & No. \\
\hline Jan. & 0 & April & 0 & July & 3 & Oct. & 1 \\
Feb. & 0 & May & 1 & Aug. & 5 & Nov. & $2^{*}$ \\
Mar. & 1 & June & 2 & Sept. & 1 & Dec. & 1 \\
\hline Totals & 1 & & 3 & & 9 & & 4 \\
\hline
\end{tabular}

* Include one case following penicillin injection.

The maximum seasonal incidence is seen to be in the summer and autumn months with sporadic cases practically throughout the year. This is amply confirmed by taking the records of all cases known (70-80 cases) when it was found that just over $50 \%$ occurred between July and September and about $30 \%$ in October-December. This seasonal incidence corresponds closely to that of poliomyelitis.

Association with Cases of Poliomyelitis. In only two cases out of 17 was a history of poliomyelitis in the same district obtained; in one of these it occurred in another member of the family. Detailed enquiry from local health authorities regarding poliomyelitis in the corresponding districts was not made. There is, however, some suggestive evidence in the records of the larger series studied that groups of cases occurred in areas in which there was a high incidence of poliomyelitis at the time.

\section{Discussion}

The diagnosis made in almost every case studied was that of poliomyelitis. In general no enquiry as to recent inoculations or injections was made until a later date. The question remains to be answered whether the relationship between an inoculation and subsequent paralysis is fortuitous, as these children were in a common age group for both immunization and poliomyelitis. The true incidence of such an association is difficult to obtain. A study of two sets of poliomyelitis records, taken at random, was made in different hospitals. In one series of $\mathbf{8 0}$ cases of poliomyelitis, three were found in which a paralysis of one limb occurred within a month of inoculation. In the other series of 56, seven such cases were discovered. No survey of large numbers of recently immunized children has been made to see if any became paralysed. A possible source of evidence has been obtained from the survey of poliomyelitis in England and Wales in 1947 organized by the Public Health Laboratory Service (McFarlan, 1949), which disclosed that there were 495 cases in children under the age of ten years. In 14 of these a definite history was obtained of immunization against diphtheria or pertussis within one month of paralysis. Eleven of these cases occurred in 308 poliomyelitis cases aged under five years, i.e. in the common age group for inoculation. Brain (1943) discussing the neurological sequelae of inoculations refers to three cases of poliomyelitis following diphtheria toxoid occurring when the disease was already prevalent. He points out that the relationship of the infection to the inoculation is at present unsettled and that before deciding it exists it is necessary to ascertain statistically that the incidence is higher among immunized children than in the community at risk. In any case, when the number of inoculations given is considered these complications are obviously rare.

Various factors suggest themselves as being of possible aetiological significance.

Toxins or Virus Introduced with the Injection. The possibility of toxins or virus contaminants contained in the material injected was considered. Under the Therapeutic Substance Act Regulations products of this nature are not allowed to be issued if they contain any free toxins. 'Batch' samples returned to the manufacturers were injected into 
animals and no specific reactions were observed. They were also found to be sterile on culture.

The possibility of contamination is remote even with a virus, and if it did occur the makers state that the virus would be inactivated during the manufacturing process. Furthermore, no two cases of paralysis occurred in which the same batch or even the same bottle of material was used. Introduction of a virus at the time of injection has to be considered. A few enquiries indicate that a fresh needle is used for each injection, though the same syringe is employed several times. If a virus were introduced from the syringe in the same way as serum hepatitis occurs, one would expect multiple cases from one inoculation session rather than isolated examples, as in fact occurred. Moreover it has yet to be shown that such a virus causing paralysis can be conveyed from one human being to another in this way. It would be reasonable also to expect more cases to occur after any other intramuscular injection. Hughes (1944) has suggested, but without any direct evidence, that cases following injections of serum might be due to a virus thus introduced.

Allergy. With regard to the question of the tissues being sensitized by an initial injection, one would expect, if this were so, that all cases would occur after the second or third injection. In fact, in this series, six out of the 17 patients were paralysed following the first injection. Of a further 40 cases in which details are known this occurred in eleven.

Reactivation of a Latent Virus within the Tissues. Again the condition should be very much commoner after any other intramuscular injection unless there is something specific in immunizing agents which reactivates a dormant virus. Keim (1939) and Keim and Wakefield (1940) discuss such possibilities with some favour. Such a theory in the present state of knowledge is unattractive on the grounds that it is difficult to verify.

Brachial Neuritis. Neurological complications following the administration of serum have been recognized for some time (Allen, 1931; Smith 1939; and other workers). Allen gives a good description. Injection of serum was followed by an attack of serum sickness within five to ten days. Two to five days later, or if serum sickness did not occur within two to five days of its expected date, one of four possible sequelae was seen: paralysis of a radicular type (Cases 5 and 6 ) accompanied by much pain (sensory loss was rare but where present it involved the outer aspect of the upper arm) ; neuritic; polyneuritic; or cerebral disturbance. Lumbar puncture was not performed in these cases. The pathogenesis postulated was oedema of the nervous tissue occurring during the serum sickness.
More recently a number of writers have reported series of cases, particularly in the Near East, of 'brachial neuritis' (Parsonage and Turner, 1948; Spillane, 1943; Wyburn-Mason, 1941; Dixon and Dick, 1945; Turner, 1944). One of the best descriptions is given by Parsonage and Turner under the title 'neuralgic amyotrophy, the shoulder girdle syndrome. Only a certain proportion of their cases were of the same distribution as the $\mathbf{1 2}$ mentioned in this series. Moreover, they differ in the accompaniment of severe pain, some sensory loss, and in particular the absence of constitutional symptoms and changes in the C.S.F. In many papers cases which were preceded by injections or trauma are excluded. Paul et al. (1944) tried to isolate poliomyelitis virus from the faeces of six cases of the syndrome and were unsuccessful, but obtained the virus from nine out of fifteen cases of poliomyelitis. Parsonage and Turner conclude that the complete clinical similarity between their cases and the serum cases make it reasonable to assume that they are of similar aetiology, although this remains unknown. Spillane (1943), discussing trauma and injections as aetiological agents, excludes the former on history, and the latter on similar grounds and on the fact that the majority of his cases involved the right arm and injections are usually given in the left. In the vast majority of cases in this series paralysis affected the left arm into which inoculations are most commonly given.

There is comparatively little in the literature giving examples following immunization similar to those recorded in this paper. Walshe (1945) under the heading ' brachial neuritis' makes reference to it occurring after tetanus antitoxin, diphtheria antitoxin, T.A.B., etc. His description of these cases is similar to that of other writers mentioned above. Pain is a prominent feature, paralysis is often bilateral and involves chiefly the deltoid, serratus anterior, rhomboids, spinati, and triceps; sensory loss is minimal and may be absent. No mention is made of constitutional symptoms or changes in the cerebrospinal fluid. In the series described by Parsonage and Turner enquiry was made regarding recent vaccination and inoculations in 67 patients. Of these 11 had had inoculations during the four weeks preceding the onset of their shoulder girdle symptoms, which included T.A.B., tetanus toxoid, and typhus vaccine (European). Clinically these cases differed from my series in the manner already described. Turner (1944) in describing 36 cases of 'brachial neuritis' states that there is nothing comparable to it in the legs.

Anterior Poliomyelitis. The distribution and course of those cases of paralysis as it affected the 
leg are sufficiently similar to poliomyelitis to need no further comment. The virtually segmental distribution of paralysis affecting the arm appears at first sight a little unlike infantile paralysis, but a study of poliomyelitis records suggests that it can occur. The muscles most commonly affected (Wilson 1940) are the deltoid and upper arm muscles.

Wilson (1940) recording the findings of four authors in different epidemics gives the age incidence as $6-15 \%$ occurring under one year, and $42-75 \%$ occurring between one and four years. Comparable figures taken from two series of records at different hospitals in this country between 1946 and 1949 show an incidence of $6 \%$ and $11 \%$ under one year, and of $37 \%$ and $44 \%$ between one and five years.

That poliomyelitis may affect only one limb is shown in an analysis made by Lovett (1916). In 1,166 cases one leg was affected in $25.9 \%$ of cases and one arm in $7 \cdot 1 \%$. Taking two random samples of poliomyelitis from hospital records in this country, there were 56 cases, of which 7 followed within a month of inoculation in one instance, and 80 cases, which included 3 following inoculation in the other series. Omitting the post-inoculation cases, in $8 \%$ one arm was involved and in $30 \%$ one leg, which is in accord with most figures published for poliomyelitis epidemics. Such figures indicate the predominance of leg paralysis compared with the arm, and are in contrast to the cases following inoculation in which the arm is most commonly afflicted. If in the two series mentioned the postinoculation figures are included, the percentages work out at $7 \%$ arm paralysis, $7 \%$ arm paralysis after inoculation, and $28 \%$ leg paralysis. The percentage of arm cases is seen to be practically doubled and the ratio of leg to arm falls from 4 to 1 to 2 to 1 . Such a comparison may not be statistically significant, and of course inaccuracies arise, as inoculations are not by any means always recorded in the case histories of poliomyelitis. Nevertheless it does suggest that inoculation may determine the site of paralysis. The analogy of the relationship between tonsillectomy and poliomyelitis immediately occurs. It is recognized that tonsillectomy does not increase the chances of infection, but if a person is to get the disease the chances of it being of the bulbar variety become extremely high (Horstmann, 1948).

Further ideas along these lines are given by Russell (1949) in an article on paralytic poliomyelitis. In discussing the effect of trauma he quotes Levinson et al. (1945) as having reported a few cases in which local trauma appeared to determine the site of maximum paralysis. That peripheral trauma provides the virus with easy access to the neurones, or that it modifies the physiology of the spinal cord cells of the segments concerned in such a way as to make them more vulnerable to the virus, he suggests as possibilities. Two cases of paralysis following T.A.B. and penicillin injections respectively are reported. Commenting on these it is postulated that the trauma of injection might possibly increase the vulnerability of that part of the spinal cord which supplies the site of injection.

\section{Prophylaxis}

Despite the fact that the relationship between inoculation and subsequent paralysis has not been proved statistically, the association, though uncommon, would appear to be of sufficient importance to make one consider prophylactic measures. Further, if the public comes to associate inoculation with the possible risk of paralysis, the immunization campaign may thereby fall into some disrepute. In view of this possibility, taken in conjunction with the seasonal incidence, it might well prove wise to suspend inoculations during part of the year, or in areas where poliomyelitis is prevalent. It is admitted that any measure affecting the immunization campaign must be given most careful thought lest more harm than good ensue.

\section{Summary}

Seventeen cases are described in which paralysis of a single limb has occurred within 28 days of receiving an injection. Of these fifteen followed immunization and two penicillin.

The aetiology is discussed. The facts pointing to poliomyelitis are the constitutional symptoms, the changes in the cerebrospinal fluid, and the seasonal incidence.

The question of the trauma of an injection determining the site of maximum paralysis is discussed.

It is concluded that there is a case for considering the suspension of immunization during an outbreak of poliomyelitis.

I am indebted to the medical staffs of the Hospital for Sick Children, Great Ormond Street, and the Evelina Hospital for Sick Children for permission to publish their cases; to the medical superintendents of the Western Fever Hospital and Queen Mary's Hospital, Carshalton, for giving me access to their poliomyelitis files; to Dr. A. H. Gale, of the Ministry of Health, for helpful advice and reports on additional cases; and to Dr. P. R. Evans for criticism and encouragement. 
APPENDIX A

\begin{tabular}{|c|c|c|c|c|c|}
\hline $\begin{array}{l}\text { Case No. } \\
\text { and Sex }\end{array}$ & Age & Site and Type of Inoculation & Dates Given & Onset & $\begin{array}{l}\text { Incubation } \\
\text { Period }\end{array}$ \\
\hline $\begin{array}{l}\text { 1. A.W. } \\
\text { Male }\end{array}$ & 1.t. years & $\begin{array}{l}\text { Left arm } \\
\text { A.P.T. and pertussis }(0.5 \mathrm{ml}) \\
\quad " \quad \Longrightarrow \quad \Longrightarrow \quad(0.5 \mathrm{ml}) \\
\quad \Rightarrow \quad \Longrightarrow \quad(0.5 \mathrm{ml})\end{array}$ & $\begin{array}{l}27.5 .48 \\
24.6 .48 \\
22.7 .48\end{array}$ & $\begin{array}{l}\text { 13.8.48 } \\
\text { Off colour one day before } \\
\text { paralysis }\end{array}$ & 22 days \\
\hline 2. M.G. & $10 \frac{1}{2}$ months & $\begin{array}{l}\text { Left deltoid } \\
\text { Pertussis }(0.5 \mathrm{ml} .) \\
\text { A.P.T. }(0.2 \mathrm{ml}) \\
\text { Pertussis }(0.5 \mathrm{ml}) \\
\text { A.P.T. } \quad(0.2 \mathrm{ml})\end{array}$ & $\begin{array}{l}\text { About } \\
12.8 .48 \\
\text { About } \\
12.9 .48\end{array}$ & $\begin{array}{l}12.10 .48 \\
\text { 'Cold' with running nose } \\
7 \text { days before onset. } \\
\text { Another case of A.P.M. } \\
\text { in vicinity }\end{array}$ & 28 days \\
\hline $\begin{array}{l}\text { 3. J.M. } \\
\text { Male }\end{array}$ & 10 months & $\begin{array}{l}\text { Arm } \\
\text { Pertussis }(0.5 \mathrm{ml}) \\
\text { A.P.T. } \quad(0.2 \mathrm{ml} .)\end{array}$ & 6.5 .48 & $\begin{array}{l}14.5 .48 \\
\text { Feverish and miserable } \\
\text { after the onset }\end{array}$ & 8 days \\
\hline $\begin{array}{l}\text { 4. P.H. } \\
\text { Female }\end{array}$ & 7 months & $\begin{array}{c}\text { Left arm } \\
\text { Pertussis }(0.5 \mathrm{ml} .) \\
\Rightarrow \quad(0.5 \mathrm{ml}) \\
\Rightarrow \quad(0.5 \mathrm{ml})\end{array}$ & $\begin{array}{r}23.1 .47 \\
6.2 .47 \\
20.2 .47\end{array}$ & $\begin{array}{l}\text { 8.3.47 } \\
\text { Drowsy on 2.3.47. Fret- } \\
\text { ful on 8.3.47 }\end{array}$ & 16 days \\
\hline $\begin{array}{l}\text { 5. M.P. } \\
\text { Female }\end{array}$ & $2 \frac{10}{2}$ years & $\begin{array}{l}\text { Left arm } \\
\text { A.P.T. }(0 \cdot 3 \mathrm{ml} .)\end{array}$ & 16.7.48 & $\begin{array}{l}31.7 .48 \\
\text { Upper respiratory infec- } \\
\text { tion and tonsillitis. } \\
18.7 .48 \\
\text { Fretful and lethargic }\end{array}$ & 15 days \\
\hline $\begin{array}{l}\text { 6. J.C. } \\
\text { Female }\end{array}$ & $6 \frac{1}{2}$ months & $\begin{array}{l}\text { Left arm } \\
\text { A.P.T. }(0 \cdot 2 \mathrm{ml}) \\
\text { A.P.V. }(0 \cdot 5 \mathrm{ml} .)\end{array}$ & 16.7 .45 & Head cold on 30.7 .45 & 26 days \\
\hline $\begin{array}{l}\text { 7. D.J. } \\
\text { Male }\end{array}$ & 1 year & $\begin{array}{l}\text { Left arm } \\
\text { A.P.T. } \\
\text { A.P.T. }\end{array}$ & $\begin{array}{l}\text { End of Sept. } \\
25.10 .45\end{array}$ & $\begin{array}{l}11.11 .45 \\
\text { Day before onset child } \\
\text { was fretful and refused } \\
\text { to eat }\end{array}$ & 17 days \\
\hline $\begin{array}{l}\text { 8. G.J. } \\
\text { Male }\end{array}$ & 10 months & $\begin{array}{l}\text { Left arm } \\
\text { A.P.T. and pertussis }(0.5 \mathrm{ml} \text {.) }\end{array}$ & 28.7.48 & $\begin{array}{l}15.8 .49 \\
\text { Feverish and fretful for } \\
2 \text { days before onset. } \\
\text { Vomiting }\end{array}$ & 18 days \\
\hline $\begin{array}{l}\text { 9. K.G. } \\
\text { Male }\end{array}$ & $1 \frac{1}{2}$ years & $\begin{array}{l}\text { Two injections against } \\
\text { diphtheria }\end{array}$ & $\begin{array}{c}\text { End of May, } \\
1947\end{array}$ & $\begin{array}{l}11.6 .47 \\
\text { Coryza } 10 \text { days before } \\
\text { onset; lasted } 3 \text { days. } \\
\text { Then off food. Feverish, } \\
\text { miserable, and no appetite } \\
3 \text { days before onset }\end{array}$ & $7-14$ days \\
\hline
\end{tabular}




\begin{tabular}{|c|c|c|c|c|c|}
\hline $\begin{array}{l}\text { Case No. } \\
\text { and Sex }\end{array}$ & Age & Site and Type of Inoculation & Dates Given & Onset & $\begin{array}{c}\text { Incubation } \\
\text { Period }\end{array}$ \\
\hline $\begin{array}{l}\text { 10. M.J. } \\
\text { Female }\end{array}$ & $2 \frac{1}{4}$ years & A.P.T. & Aug., 1947 & $\begin{array}{l}5.9 .47 \\
\text { Three weeks before } \\
\text { onset had } 3 \text { fits in one } \\
\text { day. Associated with } \\
\text { coryza which lasted one } \\
\text { week }\end{array}$ & 2-3 weeks \\
\hline $\begin{array}{l}\text { 15. C.S. } \\
\text { Female }\end{array}$ & 15 months & $\begin{array}{l}\text { Left arm } \\
\text { A.P.T. }(0.5 \mathrm{ml} .) \\
\text { A.P.T. }(0.5 \mathrm{ml})\end{array}$ & $\begin{array}{l}20.5 .49 \\
17.6 .49\end{array}$ & $\begin{array}{l}20.6 .49 \\
\text { T. } 103^{\circ} \text { on night of injec- } \\
\text { tion. Next day arm weak. } \\
\text { June } 20 \text { left arm paralysed. } \\
\text { June } 21 \text { or } 22 \text { neck stiff- } \\
\text { ness noted }\end{array}$ & 3 days \\
\hline $\begin{array}{l}\text { 12. J.F. } \\
\text { Female }\end{array}$ & $1 \frac{10}{2}$ years & $\begin{array}{l}\text { Left buttock } \\
\text { A.P.T. } \\
\text { A.P.T. }\end{array}$ & $\begin{array}{l}\text { Unknown } \\
20.6 .48\end{array}$ & $\begin{array}{l}11.7 .48 \\
\text { Pyrexial for } 4 \text { days before } \\
\text { onset }\end{array}$ & 21 days \\
\hline $\begin{array}{l}\text { 13. J.H. } \\
\text { Female }\end{array}$ & 1 year & $\begin{array}{l}\text { Right buttock } \\
\text { A.P.T. and pertussis }\end{array}$ & 28.7.48 & $\begin{array}{l}7.8 .48 \\
\text { Fretful, feverish and } \\
\text { drowsy for } 48 \text { hours } \\
\text { before onset. Leg tender } \\
\text { but no local inflamma- } \\
\text { tion }\end{array}$ & 10 days \\
\hline 14. M.L. & 18 months & $\begin{array}{l}\text { Buttock } \\
\text { A.P.T. } \\
\text { A.P.T. }\end{array}$ & $\begin{array}{r}3.7 .47 \\
31.7 .47\end{array}$ & $\begin{array}{l}\text { Aug., } 1947 \\
\text { Pyrexia } 7 \text { days after in- } \\
\text { oculation. Three days } \\
\text { later both legs weak, left } \\
\text { worse than right. Latter } \\
\text { recovered in } 2 \text { days }\end{array}$ & 10-14 days \\
\hline $\begin{array}{l}\text { 15. J.B. } \\
\text { Female }\end{array}$ & 16 months & $\begin{array}{l}\text { Both arms } \\
\text { A.P.T. } \\
\text { A.P.T. }\end{array}$ & $\begin{array}{l}\text { Oct., } 1944 \\
28.11 .44\end{array}$ & $\begin{array}{l}\text { '2.12.44 } \\
\text { 'Off colour' for } 2 \text { days } \\
\text { before paralysis }\end{array}$ & 14 days \\
\hline $\begin{array}{l}\text { 16. J.H. } \\
\text { Female }\end{array}$ & 18 months & $\begin{array}{l}\text { Buttocks } \\
\text { Five injections of penicillin } \\
\text { for boils }(100,000 \text { units b.d.) }\end{array}$ & $\begin{array}{l}15.10 .48 \\
16.10 .48 \\
17.10 .48\end{array}$ & 3.11 .48 & 16 days \\
\hline $\begin{array}{l}\text { 17. M.G. } \\
\text { Female }\end{array}$ & 14 months & $\begin{array}{l}\text { Buttocks } \\
\text { Four injections of penicillin } \\
\text { for "ulcerated throat" }\end{array}$ & $\begin{array}{l}20.6 .47 \\
21.6 .47 \\
22.6 .47\end{array}$ & $\begin{array}{l}5.7 .47 \\
\text { Some difficulty in walk- } \\
\text { ing. 2.7.47. Bad tem- } \\
\text { pered and vomiting. } \\
\text { Pyrexial } 28.6 .47\end{array}$ & 13 days \\
\hline
\end{tabular}


Case

No.

Clinical Examination

Reflexes

1 27.8.48. Cranial nerves, legs and right arm normal. Left arm hangs by his side. Flaccid paralysis. Deltoid, spinati, biceps, brachialis, triceps no contraction. Pectoralis major acting. Flexors and extensors of wrist acting well. Uses hand. Good grip.

Triceps, biceps and supinator jerks on the left absent. Other tendon reflexes normal. Flexor plantar responses.

2 16.10.48. Cranial nerves, legs and right arm normal. Left arm, trapezius acting. Supraspinatus, infraspinatus, teres major, teres minor not tested satisfactorily. Pectoralis major, rhomboids, serratus anterior and latissimus dorsi appeared to be acting. Deltoid, triceps and biceps paralysed. Extensors of wrist weak. Flexors of wrist and small hand muscles appear to be acting.

3 9.8.48. Widespread flaccid paralysis of right shoulder girdle and arm. Marked wasting of deltoid. Cranial nerves normal. Legs and left arm normal.

Triceps, biceps and supinator jerks on the left absent.

Triceps, biceps, and supinator jerks absent on the right. Other tendon reflexes normal.

10.3.47. Temperature 99. Would not move head or sit up. Flaccid paralysis of left arm including the shoulder girdle, biceps and triceps groups, flexors and extensors of the wrist. Some movement of the fingers.

5 4.8.48. Onset of flaccid paralysis of left arm. Four days before being seen as an out-patient cranial nerves, legs, and right arm, normal. Left arm. Shoulder

Biceps, triceps and supinator jerks absent on girdle muscles, triceps, biceps, brachialis no contraction. Extensors and flexors of wrist, smaH muscles of hand, no abnormality detected. No wasting or fibrillation. No tenderness or pain. 


\begin{tabular}{l} 
Electrical Reactions \\
\hline 30.8 .48 . Deltoid, triceps, \\
pectoralis major, rhomboids, \\
infraspinatus, teres major and \\
minor showed no response to \\
faradism. Biceps gave a flicker. \\
Trapezius, serratus anterior \\
fore-arm muscles, and small \\
muscles of the hand responded \\
to faradism.
\end{tabular}

22.10.48. Deltoid gave no response to faradism. Triceps, biceps, rhomboids, latissimus dorsi, pectoralis major, and serratus anterior gave very weak response. Remaining muscles gave good response.

11.8.48. Rhomboids, teres, latissimus dorsi, serratus anterior, pectoralis major, deltoid, biceps, triceps, extensor indicis, extensor communis digitorum, extensor ulnaris, extensor carpi radialis longus and brevis-no response to faradism. Opponens pollicis, abductor pollicis brevis-no response to faradism. Trapezius gave a good response to faradism. Extensor pollicis longus, abductor pollicis brevis, extensor minimi digitis, flexors of wrist and small muscles of hand gave weak response 5.8.49. Biceps and triceps gave a weak flicker on faradic stimulation.

20.9.48. Trapezius, pectoralis major, flexors and extensors of wrist, small muscles of hand gave a good response to faradism. Teres major, spinati, rhomboids, biceps and triceps gave a sluggish response to faradism. Serratus anterior and deltoid gave no response to faradism.

\begin{tabular}{c|c}
\hline C.S.F. & \multicolumn{1}{|c}{ Follow-up } \\
\hline- & $\begin{array}{l}15.9 .48 . \text { Biceps and brachialis now acting. } \\
\text { Supinator jerk (left) obtained. } \\
29.9 .48 . \text { Triceps now acting. Rhomboids } \\
\text { normal. } \\
\text { 19.10.48. Spinati wasted. Flicker in deltoid. } \\
\text { Biceps jerk present. } \\
\text { 11.3.49. Raises arm above head. Only muscle } \\
\text { completely knocked out, infraspinatus. }\end{array}$ \\
\hline
\end{tabular}

16.10.48. Clear-cells, 17 per c.mm. Protein, $30 \mathrm{mg}$. Sugar, 40. Chlorides, 720. Culture sterile.

27.10.48. Clear-cells, 1 per c.mm. Protein, 45 mg. Sugar, 59. Chlorides, 740.
18.10.48. Weak action of biceps. Forearm muscles and hand much stronger.

1.11.48. No contraction of deltoid, moving arm more freely. 'Trick' movements at shoulder. Supinator jerk obtained. Biceps and triceps still absent.

$-1$

10.1.49. Beginning to use hand.

20. Small muscles of hand, flexors and extensors of wrist now acting well. ? flicker in triceps. Biceps group, deltoid, spinati, pectorals, no action.

5.8.49. Flexors of wrist and hand 5. Extensors of wrist 4. Biceps and triceps 0 . Deltoid and spinati 0 . Pectorals, teres major, latissimus dorsi-flicker. Trapezius 5 .

12.4.47. Lifting head. Flexors and extensors of wrist, small muscles of hand acting well. Deltoid, spinati, biceps and triceps wasted and not acting. 20.9.48. Flexors and extensors of wrist, small muscles of hand acting well. Deltoid, spinati, biceps and triceps not acting. Trapezius, pectoralis major, rhomboids, teres major acting.

23.9.48. Trapezius, serratus anterior, pectoralis major acting, spinati, deltoid, triceps; paralysed and wasted. Biceps and brachialis, some wasting, weak contraction 3. Reflexes, weak supinator jerk.

28.10.48. Deltoid and spinati remain wasted. Triceps 3. Biceps 4.

24.2.49. Much improved. Can now use deltoid and raises arm above head. 


\section{Case}

No.

Reflexes

$6 \quad$ 15.8.45. Cranial nerves, transient left facial weakness noted. Legs and right arm normal. Left arm, complete flaccid paralysis. No wasting.
Biceps, triceps, supinator jerks absent on the left. Other tendon reflexes normal. Flexor plantar responses.
7 14.11.45. Temperature $100 \cdot 4^{\circ} \mathrm{F}$. Flushed. No neck rigidity. Flaccid paralysis of left arm, including shoulder girdle muscles, biceps, triceps, and fore-arm muscles. Cranial nerves, legs and right arm normal.
Biceps, triceps and supinator jerks absent on the left. Other tendon reflexes normal. Flexor plantar responses.
8 15.8.48. Temperature $100^{\circ}$ F. Neck rigidity. Cranial nerves, right arm and legs normal. Left arm, flaccid paralysis of shoulder and arm muscles. Extensors and flexors of wrist, small muscles of hand acting.
9 12.6.47. Temperature $100^{\circ} \mathrm{F}$. Some neck rigidity. Cranial nerves, right arm, and right leg normal. Left arm, flaccid paralysis of muscles of left shoulder and arm. Moves wrist and hand. Some weakness of flexors and extensors of wrist and muscles of hand.
Biceps, triceps, supinator jerks absent on the left. Other tendon reflexes normal. Flexor plantar responses.
Triceps, biceps, supinator, knee jerks absent on the left. Other tendon reflexes normal. Flexor plantar responses.
$10 \quad 5.9 .47$. Temperature $100 \cdot 6^{\circ}$ F. No neck rigidity. Cranial nerves, left arm, and legs normal. Right arm, trapezius functioning. Flaccid paralysis of shoulder girdle muscles, biceps, triceps. Flexors and extensors of wrist, small muscles of hand normal.
Triceps, biceps jerks absent on the right. Other tendon reflexes normal.
11 25.6.49. Apyrexial. No neck rigidity. Cranial nerves, right arm normal. Legs, some loss of power in legs, right more than left. Left arm, flaccid paralysis of left shoulder girdle and arm muscles. Muscles of fore arm weak. Moving hand.
Triceps, biceps, supinator jerks absent on the left. Other tendon reflexes normal. Flexor plantar responses. 


\begin{tabular}{|c|c|c|}
\hline Electrical Reactions & C.S.F. & Follow-up \\
\hline $\begin{array}{l}\text { 30.6.47. Entirely normal ex- } \\
\text { cept for some weakness of } \\
\text { response of triceps. } \\
\text { 30.6.47. X-ray, small bilateral } \\
\text { cervical ribs. }\end{array}$ & $\begin{array}{l}\text { 15.8.45. Clear fluid. Cells } \\
3 \text { per c.mm. }\end{array}$ & $\begin{array}{l}\text { 17.6.47. Marked wasting of all muscles of left } \\
\text { arm. Slight wasting of thenar eminence. Shoulder } \\
\text { girdle, muscles with the exception of deltoid and } \\
\text { spinati appear to act well. Voluntary movement } \\
\text { in left arm quite good. Picks up objects with } \\
\text { hand. Grip weak. } \\
27.10 .48 \text {. Residual weakness of deltoid and } \\
\text { triceps. Some wasting of muscles of forearm. } \\
\text { All movements full and free. All tendon reflexes } \\
\text { obtained. } \\
19.8 .49 \text {. Left arm smaller than right with one } \\
\text { inch of shortening of forearm. Deltoid } 4 . \\
\text { Triceps 3. Other muscles acting well. }\end{array}$ \\
\hline $\begin{array}{l}\text { 8.12.46. Pectorals, scapular } \\
\text { muscles, no response to fara- } \\
\text { dism, flicker to galvanism. } \\
\text { Deltoid, biceps, triceps, no } \\
\text { response to faradism. Weak } \\
\text { galvanic response. Extensors } \\
\text { and flexors of wrist appeared to } \\
\text { respond normally. Child } \\
\text { uncooperative. }\end{array}$ & $\begin{array}{l}\text { 15.8.45. Turbid fluid. Pro- } \\
\text { tein, } 15 \text { mg. Cells, R.B.C., } \\
\text { 2,500; Sugar, } 65 \text {; Chlorides, } \\
\text { 740. Culture sterile. }\end{array}$ & $\begin{array}{l}\text { 16.5.46. Marked weakness of all muscles of } \\
\text { left shoulder and arm. } \\
12.7 .46 \text {. Paralysis of shoulder girdle, deltoid, } \\
\text { biceps and triceps. Wrist and hand muscles } \\
\text { functioning well. } \\
6.12 .46 \text {. No change, marked wasting of affected } \\
\text { muscles. }\end{array}$ \\
\hline $\begin{array}{l}\text { 17.11.48. Deltoid, biceps, and } \\
\text { triceps showed the reaction of } \\
\text { degeneration. }\end{array}$ & $\begin{array}{l}\text { 16.8.48. Clear, colourless } \\
\text { fluid; W.B.C., 50 per c.mm. } \\
\text { (predominantly lymphocytes); } \\
\text { R.B.C., 10 per c.mm. protein, } \\
30 \text { mg.; chlorides, } 710 ; \text { sugar } \\
\text { normal. Culture sterile. }\end{array}$ & $\begin{array}{l}\text { 31.8.48. Some wasting of spinati. No move- } \\
\text { ment at shoulder. Biceps and triceps group } \\
\text { paralysed. } \\
\text { 26.10.48. Pectorals, latissimus dorsi, trapezius } 5 \text {. } \\
\text { Deltoid and spinati } 0 \text {. Triceps } 0 \text {. Biceps } 1 \text {. } \\
\text { Fore-arm and muscles of hand 5. }\end{array}$ \\
\hline - & $\begin{array}{l}\text { 13.6.47. Clear, colourless } \\
\text { fluid. Cells, } 8 \text { lymphocytes; } \\
\text { protein, 40 mg.; (negative } \\
\text { Pandy); chlorides, 740; cul- } \\
\text { ture sterile. } \\
\text { 18.6.47. Clear, colourless } \\
\text { fluid. Cells, } 1 \text { lymphocyte and } \\
3 \text { R.B.C.'s ; protein } 50 \mathrm{mg} \text {; } \\
\text { chlorides, 730; culture sterile. }\end{array}$ & $\begin{array}{l}\text { 16.6.47. Muscle tone and reflexes in left leg } \\
\text { normal. } \\
29.8 .47 \text {. Deltoid and abductors of shoulder } 0 . \\
\text { Biceps and Triceps } 0 \text {. Extensors of wrist } 2 \text {. } \\
\text { Flexors of wrist 4-5. Grip 5. } \\
4.2 .49 \text {. Rhomboids, teres major, pectorals, } \\
\text { latissimus dorsi 5. Spinati, deltoid, biceps, } \\
\text { triceps } 0 \text {. Supinatus and pronators } 1 \text {. Extensors } \\
\text { of wrist 2. Flexors of wrist, small muscles of } \\
\text { hand 5. }\end{array}$ \\
\hline - & $\begin{array}{l}\text { 5.9.47. Clear, colourless } \\
\text { fluid. Cells, } 30 \text { polymorphs; } \\
39 \text { lymphocytes; } 10 \text { R.B.C.'s } \\
\text { protein, } 20 \text { mg.; chlorides, } \\
710 ; \text { sugar present; culture } \\
\text { sterile. }\end{array}$ & $\begin{array}{l}\text { 11.10.47. Triceps beginning to act. Otherwise } \\
\text { no change. Tendon reflexes-weak triceps jerk } \\
\text { obtained. } \\
\text { 31.10.47. Immunized with A.P.T. and pertussis } \\
\text { vaccine. Left arm. } \\
27.11 .47 \text {. Immunized with A.P.T. and pertussis } \\
\text { vaccine. Left arm. } \\
\text { 11.2.49. Rhomboids, pectorals, latissimus dorsi, } \\
\text { teres major, serratus anterior 5. Spinati wasted, } \\
\text { some action. Deltoid, wasted 0. Biceps group 4. } \\
\text { Triceps } 4 \text {. Fore-arm and hand 5. All tendon } \\
\text { reflexes obtained. }\end{array}$ \\
\hline 一 & $\begin{array}{l}\text { 25.6.49. Clear, colourless fluid. } \\
\text { Cells, 19; protein, } 50 \mathrm{mg} \text {. } \\
\text { sugar, } 61 \text {; chlorides, } 729 .\end{array}$ & $\begin{array}{l}\text { Latissimus dorsi, rhomboids, trapezius, teres } \\
\text { major } 5 \text {. Pectorals appear to be acting. Deltoid, } \\
\text { spinati, biceps and triceps } 0 \text {. Extensors of wrist } 4 \text {. } \\
\text { Flexors of wrist and hand } 5 \text {. }\end{array}$ \\
\hline
\end{tabular}


Case

No.

Clinical Examination

Reflexes

12 12.7.48. Admitted to hospital. Cranial nerves, right arm and legs normal. Spinal muscles, some weakness. Left arm, flaccid paralysis of left shoulder girdle and arm muscles.

13 8.9.48. Cranial nerves, arms and left leg normal. Right leg, before onset of paralysis could stand, but Ankle and knee jerks on the right absent. Other not walk. Able to sit up. Flaccid paralysis of right reflexes normal. hip girdle and leg muscles. Movement of toes only.

14 15.9.47. Cranial nerves, right leg and arms normal. Left leg, marked lordosis. Waddling gait, with left thigh externally rotated. No gross wasting. Foot drop.

15 15.12.44. Apyrexial. Walked at one year, now unable to do so. Cranial nerves, arms and right leg normal. Left leg. tenderness of muscles noted. Anterior tibial group paralysed. tendon reflexes normal. Flexor plantar responses.

Knee and ankle jerks absent on left. Other

16 4.11.48. Temperature $100 \cdot 4^{\circ}$ F. Not using right leg. Sitting up. Cranial nerves, arms and left leg, trunk muscles normal. Right leg, flaccid paralysis ; movement of toes only. Glutei, quadriceps, hamstrings, anterior and posterior tibials, peronei paralysed.

Knee and ankle jerks absent on the right. Other tendon reflexes normal. Flexor plantar responses.

\subsubsection{Right leg giving way on walking.}




\begin{tabular}{|c|c|c|}
\hline Electrical Reactions & C.S.F. & Follow-up \\
\hline - & - & $\begin{array}{l}\text { 19.7.48. Able to raise hand. } \\
\text { 9.8.48. Paralysis of left deltoid, trapezius, } \\
\text { pectorals, latissimus dorsi, biceps and triceps } \\
\text { reported. ? weakness of left leg. } \\
\text { 19.10.48. Pectorals, latissimus, trapezius, rhom- } \\
\text { boids, acting well } 5 \text {. Spinati and deltoid wasted } \\
\text { and paralysed } 0 \text {. Biceps group weak but con- } \\
\text { tracting } 2 \text {. Triceps acting. well } 4 \text {. Flexors and } \\
\text { extensors of wrist, hand muscles acting well } 5 \text {. } \\
\text { 11.8.49. Slight residual weakness of deltoid only. }\end{array}$ \\
\hline $\begin{array}{l}\text { 20.6.49. Erector spinae, fair } \\
\text { response to faradism. Glutei, } \\
\text { hamstrings, weak response to } \\
\text { faradism. Adductors gave } \\
\text { flicker but voluntary movement } \\
\text { noted. Quadriceps, tibialis } \\
\text { anterior, no response to } \\
\text { faradism. }\end{array}$ & - & $\begin{array}{l}\text { 15.10.48. Flexion of hip by psoas and iliacus. } \\
\text { Gluteus maximus, no contraction detected. } \\
\text { Hamstrings acting against resistance. Quadriceps } \\
\text { wasted and paralysed. Adductors very weak. } \\
\text { Calf muscles, anterior tibials, and peronei acting } \\
\text { weakly. Right ankle jerk obtained. } \\
20.6 .49 \text {. Standing but not walking. Glutei } \\
\text { acting. Adductors weak. Quadriceps wasted and } \\
\text { paralysed. Tibialis anterior appears paralysed. } \\
\text { Calf muscles, tibialis posterior, peronei, flexors } \\
\text { and extensors of toes gave good response to } \\
\text { faradism. }\end{array}$ \\
\hline $\begin{array}{l}\text { 22.1.48. Tibialis anterior and } \\
\text { extensor digitorum gave no } \\
\text { faradic response. Tibialis } \\
\text { posterior and extensor hallucis } \\
\text { gave weak faradic response. }\end{array}$ & - & $\begin{array}{l}\text { 22.1.48. Half-inch wasting of calf. Paralysis of } \\
\text { tibialis anterior; ankle jerk sluggish. } \\
\text { 9.1.49. Still no action of tibialis anterior. }\end{array}$ \\
\hline $\begin{array}{l}\text { 6.2.47. Gastrocnemius, soleus, } \\
\text { posterior tibial group gave no } \\
\text { response to faradism. Quadri- } \\
\text { ceps, hamstrings, anterior } \\
\text { tibial gave good responses to } \\
\text { faradism. Adductors and } \\
\text { peronei gave a fair response. }\end{array}$ & - & $\begin{array}{l}\text { March, 1945. Residual weakness of quadriceps } \\
\text { and anterior tibial group. } \\
\text { 23.8.45. Following 'measles, the posterior } \\
\text { tibial group was noted to be weak. } \\
6.5 .46 \text {. Pes cavus with weakness of anterior } \\
\text { tibial muscles. Calf muscles and posterior tibial } \\
\text { weak. } \\
\text { 20.1.47. As above, voluntary movement present } \\
\text { but weak. Quarter inch shortening of leg. } \\
\text { Calcaneo-cavo-valgus deformity. }\end{array}$ \\
\hline - & 一 & $\begin{array}{l}\text { 12.4.49. Gluteus maximus, abductors, flexors and } \\
\text { external rotators of hip } 0 \text {. Adductors and internal } \\
\text { rotators of hips } 1 \text {. Quadriceps } 0 \text {. Hamstrings } 2 \text {. } \\
\text { Calf muscles and peronei 3. Tibialis anterior } 0 \\
\text { Tibialis posterior } 1 \text {. Flexors and extensors of } \\
\text { toes 3-4. }\end{array}$ \\
\hline $\begin{array}{l}\text { 12.9.47. All muscles in right } \\
\text { leg gave good response to } \\
\text { faradism. }\end{array}$ & - & $\begin{array}{l}\text { 12.9.47. Half-inch wasting of thigh and calf. } \\
\text { Limps with leg externally rotated. } \\
25.1 .49 \text {. Walks with a dip to the right. Some } \\
\text { wasting of right buttock and half-inch wasting of } \\
\text { right thigh. Three-quarter inch shortening of leg. } \\
\text { Glutei, quadriceps, hamstrings, tensor fascia lata } \\
\text { weak. Adductors acting well. Anterior and } \\
\text { posterior tibial groups, peronei, flexors and } \\
\text { extensors of toes full power. Tendon reflexes, } \\
\text { weak knee jerk on right. }\end{array}$ \\
\hline
\end{tabular}




\section{REFERENCES}

Allen, I. M. (1931). Lancet, 2, 1128.

Brain, R. (1943). Proc. R. Soc. Med., 36, 320.

Dixon, G. J., and Dick, T. B. S. (1945). Lancet, 2, 707.

Gale, A. H. Personal Communications.

Gutmann, E., and Guttmann, L. (1944). J. Neurol. Neurosurg. Psychiat., 7, 7.

Horstmann, D. M. (1948). Lancet, 1, 273.

Hughes, R. R. (1944). Lancet, 2, 464.

Keim, H. L., and Wakefield, R. F. (1939). Arch. Derm. Syph., Chicago, 40, 709.

Keim, H. L., abstract of previous reference, and Wakefield, R. F. (1940). Bull. Hyg., 15, 259.

Levinson, S. O., Milzer, A., and Lewin, P. (1945). Amer. J. Hyg., 42, 204.
Lovett, R. W. (1916). ' 'Treatment of Infantile Paralysis.' New York.

McFarlan, A. M. (1949). Proc. R. Soc. Med., 42, 49.

Parsonage, M. J., and Turner, J. W. A. (1948). Lancet, $1,973$.

Paul, J. R., Havens, W. P., and Van Rooyen, C. E. (1944). Brit. med. J., 1, 841.

Russell, W. R. (1949). Brit. med. J., 1, 465.

Smith, R. E. (1939). Lancet, 2, 1119.

Spillane, J. D. (1943). Lancet, 2, 532.

Turner, J. W. A. (1944). Brit. med. J., 2, 592.

Walshe, F. M. R. (1945). ' Diseases of Nervous System.' Edinburgh.

Wilson, S. A. K. (1940). ' Neurology.' London.

Wyburn-Mason, R. (1941). Lancet, 2, 662.

\section{SIXTH INTERNATIONAL CONGRESS OF PAEDIATRICS}

The Sixth International Congress of Paediatrics will be held at the end of July, 1950, in Zürich, Switzerland. President, Professor G. Fanconi, M.D.

\section{Programme}

Friday, July 21. Opening of the scientific and industrial exhibition. Opening of the public exhibition, organized by the World Health Organization, the International Red Cross, and the International Union for Child Welfare.

Friday, July 21, and Saturday, July 22. Advanced lectures, partly intended as introduction to the group lectures.

Sunday, July 23. Official reception (evening).

Monday, July 24, p.m. to Thursday, July 27. Group lectures of which six to seven will be held simultaneously.

Thursday, July 27, p.m. Excursion on the Lake of Zürich.

Friday, July 28, a.m. Second Plenary Session.

Friday, July 28 , p.m. Group lecture held jointly with the International Union against Venereal Disease.

Friday, July 28. Banquet.

Friday, July 28 and Saturday, July 29. Advanced lectures.

Monday, July 31 (evening). Close of the exhibition.

During the Conference there will be demonstrations and conducted tours through a number of laboratories, hospitals and welfare institutions. Tours of historical interest will be arranged and also a special programme for ladies.

Last Date for Registering

The date for registering for the Congress has been deferred to Saturday, April 22, 1950, and registrations must be made with the American Express Co. Inc., Sihlporteplatz 3, Zürich, or their agencies or correspondents in the different countries.

\section{Congress Cards}

Each participant in the Congress must be in possession of a congress card which is available at the agencies and correspondents of the American Express Co. Three different types of congress cards will be issued.

Congress Card Serie " A", Sw. frs. 100. This entitles the holder to participate in all sessions, visits and receptions, including the official reception, the official banquet, and the excursion on the Lake of Zürich; also to free admission to the scientific and industrial exhibition, and receipt of all printed Congress literature.

Congress Card Serie " B", Sw. frs. 60. This card is for accompanying ladies. It entitles the holder to participate in all sessions, visits, and receptions; to free admission to the scientific and industrial exhibition; and to take part in the entertainments provided in the ladies' programme.

Congress Card Serie " C ", Sw. frs. 60. This entitles the holder to participate in all scientific sessions, to free admission to the scientific and industrial exhibition, and to receipt of all printed Congress literature.

\section{Hotel Accommodation}

Applications for hotel accommodation have to be made with the agencies or correspondents of the American Express Co. Arrangements can also be made through the American Express Co., for those travelling under restricted financial allowances, to obtain cheaper accommodation, i.e. bed, breakfast, and one meal at Sw. frs. 10. per day. 